STUDIA PRAWNO-EKONOMICZNE, t. CV, 2017

PL ISSN 0081-6841; e-ISSN 2450-8179 s. 149-160

DOI: 10.26485/SPE/2017/105/9

Jan KULESZA*

\title{
ZGODNOŚĆ Z KONSTYTUCJA DEMONSTRACYJNEGO OKAZYWANIA W MIEJSCU PUBLICZNYM LEKCEWAŻENIA NARODOWI POLSKIEMU, RZECZYPOSPOLITEJ POLSKIEJ LUB JEJ KONSTYTUCYJNYM ORGANOM - GLOSA DO WYROKU TK Z 21.9.2015 R., K 28/131
}

Słowa kluczowe: demonstracyjne lekceważenie; znieważenie; Naród Polski; Rzeczypospolita Polska; konstytucyjne organy państwa; proporcjonalność sensu largo; klauzula limitacyjna

Keywords: demonstrative disregard; insult; Polish Nation; Republic of Poland; constitutional state bodies; proportionality in a broad sense, limitative clause

Mimo że od wydania glosowanego orzeczenia upłynął już pewien czas, nie doczekało się ono satysfakcjonujących komentarzy ze strony doktryny. Glosa P. Malca-Lewandowskiego ${ }^{2}$, choć interesująca, nie wyczerpuje problematyki, która wymaga poruszenia w kontekście judykatu Trybunału, skupiając się na jednym tylko aspekcie. Orzeczenie to wymaga natomiast pogłębionej analizy zarówno z punktu widzenia prawa karnego, jak i konstytucyjnego. Nie można bowiem zgodzić się ani z rozstrzygnięciem Trybunału, ani z przyjętym tokiem rozumowania oraz przedstawioną argumentacją. Poniżej podniesione zostaną jednak jedynie najważniejsze zarzuty względem tego judykatu Trybunału.

Przede wszystkim należy zauważyć, iż problem stwarza Trybunałowi zidentyfikowanie przedmiotu ochrony art. $49 \S 1$ k.w. i wynikających z tego

* Dr, Uniwersytet Łódzki, Katedra Prawa Karnego, Wydział Prawa i Administracji; e-mail: j.w.kulesza@gmail.com

OTK-A 2015, nr 8, poz. 120.

2 P. Malec-Lewandowski, Glosa do wyroku TK z 21.9.2015 r., K 28/13, Palestra 2016/6, s. 110 i n. 
konsekwencji. Rację ma, gdy stwierdza, że przedmiotem ochrony jest porządek publiczny (pkt 1.2.3). Pogląd taki znajduje powszechne potwierdzenie w doktry$n^{3}{ }^{3}$. Następnie jednak uznaje, że przepis ten służy zapewnieniu poszanowania Narodowi, Rzeczypospolitej Polskiej oraz jej konstytucyjnym organom, zapewnieniu ich autorytetu ${ }^{4}$ i prestiżu $u^{5}$, powagi (pkt 3.2, 3.3). Jego zdaniem zapewnienie wymienionym podmiotom należnego poszanowania służy ochronie porządku publicznego ${ }^{6}$ rozumianego jako dyrektywa takiej organizacji życia publicznego, która zagwarantować ma minimalny poziom uwzględniania interesu publicznego. W interesie tym mieścić ma się, według Trybunału, wymagające autorytetu sprawne działanie konstytucyjnych organów państwa i właściwy - pozytywny - stosunek do dobra wspólnego, którym jest RP, jak również do Narodu jako suwerena (pkt 3.2). Twierdzi zatem w istocie Trybunał, że już samo demonstracyjne okazanie lekceważenia zakłóca normalne funkcjonowanie konstytucyjnych organów państwa. Jak już wskazywano ${ }^{7}$, brak jest podstaw dla twierdzenia, że nawet i znieważenie może prowadzić do zakłócenia normalnego funkcjonowania

3 Należy przyznać, że niektórzy autorzy dopatrują się jako przedmiotu ochrony również „poszanowania należnego" wymienionym w przepisie podmiotom (D. Egierska, w: J. Bafia, D. Egierska, I. Śmietanka, Kodeks wykroczeń. Komentarz, Warszawa 1974, s. 157; P. Kozłowska-Kalisz, w: M. Mozgawa (red.), Kodeks wykroczeń. Komentarz, Warszawa 2009, s. 171; W. Jankowski, w: T. Grzegorczyk (red.), Kodeks wykroczeń, Warszawa 2013, s. 212; M. Budyn-Kulik, w: P. Daniluk (red.), Kodeks wykroczeń. Komentarz, Warszawa 2016, s. 300), godności tych podmiotów (W. Kotowski, Kodeks wykroczeń. Komentarz, Warszawa 2009, s. 384; B. Kurzępa, Kodeks wykroczeń. Komentarz, Warszawa 2008, s. 205; A. Marek, Prawo wykroczeń (materialne i procesowe), Warszawa 2012, s. 118; T. Bojarski, Polskie prawo wykroczeń. Zarys wyktadu, Warszawa 2012, s. 136; tenże, w: T. Bojarski (red.), Kodeks wykroczeń. Komentarz, Warszawa 2013, s. 131; S. Hoc, Raz jeszcze o znieważeniu narodu lub RP (art. 133 k.k.) oraz demonstracyjnym lekceważeniu narodu polskiego, RP lub jej konstytucyjnych organów (art. 49 § 1 k.w.), w: J. Sawicki, K. Lucarz (red.), Na styku prawa karnego i prawa o wykroczeniach. Zagadnienia materialnoprawne oraz procesowe. Ksiega jubileuszowa dedykowana Profesorowi Markowi Bojarskiemu, t. I, Wrocław 2016, s. 170) wreszcie ich cześć (M. Budyn-Kulik, w: P. Daniluk (red.), op. cit., s. 300).

4 Tak również T. Bojarski, Polskie..., s. 136; tenże, w: T. Bojarski (red.), Kodeks..., s. 131; S. Hoc, op. cit., s. 170; M. Gołda-Sobczak, Demonstracyjne okazywanie lekceważenia w miejscu publicznym Narodowi Polskiemu, Rzeczypospolitej Polskiej lub jej konstytucyjnym organom a wolność wyrażania pogląów, Themis Polska Nova 2015/1, s. 164.

5 Do którego odwołuje się również M. Budyn-Kulik, w: P. Daniluk (red.), op. cit., s. 301.

6 Porządek publiczny jako materialna przesłanka ingerencji w wolość wypowiedzi na gruncie kolizji o charakterze wertykalnym konstytucyjnie chronionych wartości wskazywany jest również we wcześniejszych judykatach Trybunału: z 11.10.2006 r., P 3/06, OTK ZU nr 9A/2006, poz. 121; z 6.7.2011 r., P 12/09, OTK ZU nr 6A/2011, poz. 51; z 25.2.2014 r., SK 65/12, OTK ZU nr 2A/2014, poz. 13; z 12.2.2015 r., SK 70/13, OTK ZU nr 2A/2015, poz. 14.

7 J. Kulesza, Glosa do wyroku TK z 6.7.2011 r., P 12/09, Państwo i Prawo 2012/11, s. 137 i n. 
przedmiotu czynności wykonawczej (wówczas czynu z art. 135 § 2 k.k.). Tym bardziej nie można przyjąć, że jedynie okazanie lekceważenia konstytucyjnemu organowi może mieć jakikolwiek wpływ na sprawne funkcjonowanie tego organu. Jak słusznie zauważa L. Gardocki ,sama skuteczność działań instytucji publicznej, możliwość efektywnego wykonywania przez nią zadań organu władzy nie ulega [...] osłabieniu przez fakt zaistnienia mocno krytycznych, nawet znieważających wypowiedzi formułowanych w przestrzeni publicznej"8. Jeśliby lekceważenie czy zniewaga były zdolne wpłynąć na prawidłowe i efektywne funkcjonowanie organu, to należałoby go ocenić jako niezwykle słaby element w systemie organów władzy publicznej, skoro zniewaga czy przejaw lekceważenia był w stanie nań wpłynąć.

Nastapienie skutku w postaci zakłócenia normalnego funkcjonowania konstytucyjnego organu nie należy zresztą do znamion wykroczenia z art. $49 \S 1$ k.w. czy przestępstwa $z$ art. $135 \S 1$ k.k. (ewentualnie z art. $226 \S 3$ k.k.). Dowodzenie przez Trybunał, że już samo demonstracyjne okazanie lekceważenia zakłóca normalne funkcjonowanie konstytucyjnych organów państwa jest zbędne, skoro chodzi o wykroczenie o charakterze formalnym, podobnie jak o formalne przestępstwo'

Poza tym nie przekonuje założenie Trybunału, zgodnie z którym prawo penalne stanowi narzędzie właściwe dla budowania autorytetu i prestiżu konstytucyjnych organów państwa, państwa jako takiego czy Narodu. Trybunał dostrzega tę wątpliwość, zastrzegając, że ,ponieważ przepisy prawa nie mają mocy sprawczej i same w sobie nie mogą w nikim wywołać pozytywnego stosunku do tych podmiotów”, chodzi o „zapobieganie (przez prewencję zarówno generalną, jak i indywidualną) publicznemu okazywaniu negatywnego stosunku do nich (demonstracyjnemu uzewnętrznianiu braku szacunku)" (pkt 3.2). Jednak za nieakceptowalne $\mathrm{w}$ demokratycznym państwie prawnym należy uznać założenie, zgodnie z którym zagwarantowanie autorytetu, szacunku czy prestiżu organów władzy państwowej ma być wymuszane zagrożeniem - w omawianym przypadku - karą aresztu albo grzywny. Autorytet instytucji nie może być sztucznie budowany czy podtrzymywany poprzez stosowanie art. $49 \S 1$ k.w. ${ }^{10}$ Trybunał stwierdza w wyroku z 6.7.2011 r. ${ }^{11}$, że ,ppoczucie własnej godności i posiadanie autorytetu jest jednym $\mathrm{z}$ niezbędnych warunków efektywnego wykonywania

8 L. Gardocki, Europejskie standardy wolności wypowiedzi a polskie prawo karne, Państwo i Prawo 1993/3, s. 26.

9 Szerzej na temat formalnego charakteru czynu z art. 135 § 2 k.k. J. Kulesza, w: M. Królikowski,

R. Zawłocki (red.), Kodeks karny. Część szczególna, t. 1, Komentarz, Warszawa 2017, s. 143.

10 Por. ibidem, s. 26.

11 P 12/09, OTK-A 2011, nr 6, poz. 51, pkt 4.1. 
funkcji konstytucyjnie przypisanych głowie państwa". Jednak w demokratycznym państwie prawnym organy władzy publicznej, w tym organy konstytucyjne, zdobywają prestiż, szacunek i autorytet społeczny poprzez swoją działalność, a nie poprzez groźbę wdrożenia odpowiedzialności wykroczeniowej czy karnej w przypadku ich nieposzanowania. I nie stanowi prawo penalne narzędzia do podnoszenia własnego poczucia godności osobowych substratów konstytucyjnych organów państwa.

Nie można zatem również zgodzić się z Trybunałem, gdy odnosząc się do ewentualnej rezygnacji z art. $49 \S 1$ k.w., stwierdza, że mogłaby ona zostać odczytana jako wyraz braku szacunku Państwa Polskiego do samego siebie oraz wręcz zachęta do demonstracyjnego okazywania lekceważenia wskazanym w tym paragrafie podmiotom (pkt 3.4, 4). Jednocześnie nie można byłoby wówczas, jego zdaniem, wymagać takiego szacunku od innych. Rezygnacja z przesadnej kryminalizacji w postaci karalności demonstracyjnego okazania lekceważenia Narodowi Polskiemu, Rzeczypospolitej Polskiej oraz jej konstytucyjnym organom stanowiłaby raczej dowód siły państwa, które nie musi wymuszać szacunku dla samego siebie, a zwłaszcza swych organów, za pomocą groźby kary aresztu i grzywny. Jeśli wspomina Trybunał o ,istotnym aspekcie wychowawczym” art. $49 \S 1$ k.w., to wychowanie przy użyciu strachu przed sankcją i wymuszanie w ten sposób posłuchu normie stanowi metodę wychowawczą państw niedemokratycznych, a nie demokratycznego państwa prawnego stanowiącego dobro wspólne wszystkich obywateli (por. art. 1 i 2 Konstytucji).

Niekiedy, poszukując przedmiotu ochrony art. $49 \S 1$ k.w., popada Trybunał w sprzeczność. Stwierdza bowiem, że „uznanie za wykroczenie działań wyczerpujących znamiona określone w art. $49 \S 1$ k.w. wynika stąd, że godzą one nie tylko w godność osobistą piastuna, lecz także - pośrednio - w poszanowanie określonego organu konstytucyjnego, warunkiem działalności którego jest potrzebny do wypełniania obowiązków autorytet. Przedmiotem ochrony jest tu nie tyle godność osób pełniących w państwie określone funkcje, ile prawidłowe i efektywne funkcjonowanie (wymagające wszak autorytetu) konstytucyjnych organów Rzeczypospolitej” (pkt. 2.2.3). Należy zauważyć, że zdanie drugie przeczy zdaniu pierwszemu. Najpierw bowiem Trybunał stwierdza, że godność osobista piastuna stanowi bliższy indywidualny przedmiot ochrony, zaś autorytet i szacunek dla organu przedmiot dalszy. W drugim zdaniu zaś twierdzi odwrotnie, że chodzi nie o ochronę godności jednostki (która spada na dalszą pozycję jako przedmiot ochrony), lecz o prawidłowe funkcjonowanie organu (zatem przedmiot bliższy). W części dalszej tego samego passusu jest jednak zawarta interesująca myśl, 
zgodnie z którą „, «autorytet instytucjonalny udziela się piastunom określonych funkcji publicznych i odwrotnie», z czego należy wysnuć wniosek, iż lekceważenie piastuna może - choć niekoniecznie musi - być uznane za lekceważenie konstytucyjnego organu. Ocena musi być tu dokonywana przez właściwe organy a casu ad casum" (pkt. 2.2.3). Lekceważenie piastuna może zatem - choć niekoniecznie musi - być uznane za lekceważenie konstytucyjnego organu ${ }^{12}$. Należy zauważyć, że uzgodnienie kontekstu konstytucyjnego art. $49 \S 1$ k.w. prowadzi do wniosku, zgodnie z którym nie jest jego obocznym przedmiotem ochrony godność osobowych substratów konstytucyjnych organów. Nie rozwijając w tym miejscu szerszego uzasadnienia ${ }^{13}$, można jednak powołać konstytucyjną zasadę równego traktowania, której znaczenie dla omawianego kontekstu wykazał ETPC w wyroku z 14.03.2013 r. Eon $v$. Francja (skarga nr 26118/10).

Drugi główny zarzut względem glosowanego orzeczenia odnosi się do zignorowania przez Trybunał trudności dogmatycznych i praktycznych w rozgraniczeniu lekceważenia i znieważenia ${ }^{14}$. Być może dostrzegłby je, gdyby nie poprzestał na wykładni językowej i sięgnął po wykładnię dogmatyczną, historyczną, systemową, celowościową i wreszcie logiczną. Uniknąłby w ten sposób choćby utożsamienia znieważenia i zniesławienia (pkt 2.3) (5) $^{15}$ stanowiących przecież odrębne typy rodzajowe przestępstw. Uniknąłby również określania w całym uzasadnieniu judykatu lekceważenia jako wyrazu pogardy ${ }^{16}$ czy chęci zelżenia ${ }^{17}$.

12 W. Kulesza, J. Kulesza, Lekceważenie a znieważenie Narodu Polskiego, Rzeczypospolitej Polskiej, jej Prezydenta lub konstytucyjnych organów - wykroczenie a przestępstwo, w: J. Sawicki, K. Lucarz (red.), Na styku prawa karnego i prawa o wykroczeniach. Zagadnienia materialnoprawne oraz procesowe. Ksiega jubileuszowa dedykowana Profesorowi Markowi Bojarskiemu, t. 1, Wrocław 2016, s. 285. Zdaniem M. Budyn-Kulik kryterium różnicującym jest, czy lekceważenie miało miejsce podczas i/lub w związku z pełnieniem funkcji (M. Budyn-Kulik, w: P. Daniluk (red.), op. cit., s. 301).

13 Co uczyniono w: J. Kulesza, w: M. Królikowski, R. Zawłocki (red.), op. cit., s. 141-142. Rozważania tam zawarte należy tak samo odnieść do art. 49 § 1 k.w.

$14 \mathrm{Na}$ temat których uprzednio - z odwołaniem do wykładni znieważenia na gruncie Kodeksu karnego oraz wykładni historycznej: J. Kulesza, Glosa do wyroku SA w Szczecinie z 4.7.2013 r., II AKa 114/13, Państwo i Prawo 2015/5, s. 136 i n.; W. Kulesza, J. Kulesza, op. cit., s. 275 i n.

15 Co skutkuje dalszymi błędami, takimi jak choćby stosowanie do zniewagi testu prawdy i fałszu (por. pkt 3.3).

16 Jednocześnie odwołuje się Trybunał do swojego wcześniejszego judykatu z 6.07.2011 r. (P 2/09), w którym okazywanie pogardy przyporządkował przecież do znamienia zniewagi.

17 Należy przyznać, iż również w orzecznictwie sądów powszechnych zdarza się tego rodzaju błędna wykładnia, jak choćby w wyroku SA w Szczecinie z 4.07.2013 r. (II AKa 114/13, LEX Nr 1350423), w którym sąd stwierdza, że „lekceważenie [...] stanowi publiczną zniewagę". Także w doktrynie identyfikuje się niekiedy lekceważenie z wyrażaniem pogardy 
Należy ponownie podkreślić, co zostało już wcześniej wykazane ${ }^{18}$, że lżenie i okazywanie pogardy stanowi znieważenie, a nie jedynie przejaw lekceważenia. O ile lekceważenie oznacza okazywanie tylko braku szacunku (i tak również Trybunał je określa), o tyle znieważenie jest właśnie przejawem pogardy ${ }^{19}$. Trafnie podkreśla W. Kulesza, że „między zachowaniem, które oceniamy jako niestosowne, niegrzeczne czy nawet lekceważące a przestępstwem zniewagi istnieje poważna różnica w ładunku ujemnej treści społecznej"20. Wykładnia językowa wskazuje, że lekceważenie należy rozumieć jako nieliczenie się z czymś, uznawanie za bezwartościowe, nic sobie z czegoś nierobienie, nieprzywiązywanie wagi do kogoś lub czegoś, bagatelizowanie, traktowanie bez szacunku, ironizowanie ${ }^{21}$. Sa to zachowania zawierające mały ładunek negatywnego nastawienia sprawcy do przedmiotu czynności wykonawczej aż do wyrażenia pogardy, która jest już silnie nacechowana negatywnymi emocjami i stanowi zniewagę. Lekceważeniem jest zatem aktywne okazywanie tylko braku szacunku, natomiast znieważeniem coś bardziej nagannego, a mianowicie wyrażenie pogardy właśnie ${ }^{22}$.

(D. Egierska, w: J. Bafia, D. Egierska, I. Śmietanka, op. cit., s. 158; W. Kotowski, op. cit., s. 389; B. Kurzępa, op. cit., s. 206; P. Kozłowska-Kalisz, w: M. Mozgawa (red.), op. cit., s. 72; W. Jankowski, w: T. Grzegorczyk (red.), op. cit., s. 213; M. Budyn-Kulik, w: P. Daniluk (red.), op. cit., s. 301; G. Kasicki, A. Wiśniewski, Kodeks wykroczeń z komentarzem, Warszawa 2002, s. 183; M. Bojarski, Art. 49 [Lekceważenie Narodu i Państwa], w: M. Bojarski, W. Radecki, Kodeks wykroczeń. Komentarz, Legalis 2016, teza 2).

18 J. Kulesza, Glosa do wyroku SA w Szczecinie z 4.7.2013 r. ..., s. 136 i n.; W. Kulesza, J. Kulesza, op. cit., s. 285.

19 W. Kulesza, w: I. Andrejew, L. Kubicki, J. Waszczyński (red.), System prawa karnego, t. 4, cz. 2, O przestępstwach w szczególności, Ossolineum 1989, s. 735; tenże, w: J. Warylewski (red.), System Prawa Karnego. Przestepstwa przeciwko dobrom indywidualnym, t. 10, Warszawa 2016, s. 1218, 1224.

20 W. Kulesza, Zniesławienie i zniewaga. Ochrona czci i godności osobistej człowieka w prawie karnym - zagadnienia podstawowe, Warszawa 1984, s. 174.

21 Należy przyjąć, że nie stanowi lekceważenia samo traktowanie z niechęcią, jej okazanie, choćby i demonstracyjne. W art. 18 rozporządzenia Prezydenta RP Prawo o wykroczeniach z 11.07.1932 r. (Dz.U., nr 60, poz. 572) przewidziane były dwie postaci czynności sprawczej: okazanie niechęci lub lekceważenia. Art. $49 \S 1$ k.w. nie przewiduje już odpowiedzialności za pierwszą z postaci czynności sprawczej [odmiennie T. Bojarski, Polskie..., s. 136; tenże, w: T. Bojarski (red.), Kodeks..., s. 132; S. Hoc, op. cit., s. 170; Trybunał w glosowanym wyroku (pkt 3.3)]. Szerzej na temat wykładni art. 49 k.w. w kontekście jego poprzednika oraz innych przepisów prawa wykroczeń oraz karnego W. Kulesza, J. Kulesza, op. cit., s. 278-282.

22 Trybunał pominął w swoich rozważaniach również liczne poglądy wyrażane na gruncie Kodeksów karnych: z 1932 r., z 1969 r. oraz z 1997 r. dowodzące tezy przeciwnej, zgodnie z którą lekceważenie bądź okazanie braku szacunku stanowi znieważenie, szerzej J. Kulesza, Glosa do wyroku SA w Szczecinie z 4.7.2013 r. ..., s. 136 i n. 
Gdyby sięgnął Trybunał do wykładni art. 49 § 1 k.w., zauważyłby również, że może być ona dokonywana w sposób bezbrzeżnie szeroki. Niektórzy autorzy przyjmują bowiem, że możliwe jest również okazanie lekceważenia przez zaniechanie ${ }^{23}$, co powoduje, że wobec formalnego charakteru wykroczenia każde demonstracyjne okazanie braku szacunku może być kwalifikowane jako zachowanie karalne ${ }^{24}$. Aby temu zapobiec, niezbędne jest prawidłowe zastosowanie zasad wykładni oraz uzgodnienie jej kontekstu konstytucyjnego nie tylko w zakresie dochowania zasady określoności, lecz również balansowania pozostających w kolizji wartości konstytucyjnych, zgodnie z wymogami klauzuli limitacyjnej art. 31 ust. 3 Konstytucji (zwłaszcza zasady proporcjonalności sensu stricto).

Błędnie, zamiast sięgnąć do wykładni dogmatycznej art. 49 § 1 k.w., odwołuje się Trybunał, podążając za Prokuratorem Generalnym, do wykładni art. 315 k.k. z 1969 r. określającego czynność sprawcząjako „okazywanie lekceważenia” przez żołnierza przełożonemu. Stosunki między żołnierzem a jego przełożonym kształtują się inaczej niż między obywatelem a konstytucyjnymi organami państwa, nie wspominając o abstraktach w postaci Państwa Polskiego i Narodu. Zresztą w ten sposób osłabia Trybunał trafność swojej oceny konstytucyjności art. 49 § 1 k.w., skoro identyfikuje lekceważenie z „,rażącym nietaktem” czy zachowaniem, które „W stosunkach cywilnych stanowiłoby jedynie naruszenie form obyczajowych, np. grzecznościowych" (pkt 2.1.1). Czy rzeczywiście - w intencji Trybunału - art. 491 k.w. ma być stosowany do niegrzecznego czy nietaktownego zachowania względem, przykładowo, piastuna konstytucyjnego organu? Czy rolą prawa penalnego jest karanie zachowań niegrzecznych i nietaktownych?

Trzeci zasadniczy zarzut względem glosowanego orzeczenia dotyczy optyki przyjętej przez Trybunał w stosunku do relacji między art. $49 \S 1$ k.w. a wolnością wypowiedzi gwarantowaną w art. 54 ust. 1 Konstytucji. Zdając sobie sprawę z kontrowersyjności sformułowanej tezy, należy przyjąć, że nie każde zachowanie korzystające ze sfery wolności wypowiedzi w sferze publicznej musi być relacjonowane do debaty publicznej. Trybunał wychodzi z założenia, że każda wypowiedź w dowolnej formie, która odnosi się do Państwa Polskiego, Narodu

\footnotetext{
${ }^{23}$ A. Gubiński, Prawo wykroczeń, Warszawa 1989, s. 260; B. Kurzępa, op. cit., s. 206; A. Marek, op. cit., s. 118; jednoznacznie odmiennie S. Hoc, op. cit., s. 171. Zawężającą wykładnię lekceważenia przez zaniechanie zaproponowano w: W. Kulesza, J. Kulesza, op. cit., s. 286.

${ }^{24} \mathrm{Na}$ drugim końcu sytuuje się wykładnia identyfikująca demonstracyjne okazanie lekceważenia jako stanowiące przejaw niechętnej, wrogiej, antypaństwowej postawy sprawcy (M. Kulczycki, J. Zduńczyk, Kodeks wykroczeń. Popularny komentarz, Warszawa 1982, s. 71), przy czym pamiętać należy, że była ona prezentowana na gruncie nieco innego stanu prawnego i w innych realiach społeczno-politycznych.
} 
albo konstytucyjnych organów państwa, musi być oceniona pod kątem realizacji wymogów udziału w debacie publicznej oraz dopuszczalnych granic krytyki (pkt 3.3). Wydaje się natomiast, że wolność wypowiedzi, w tym również wypowiedzi odnoszącej się do wskazanych podmiotów, kształtuje się szerzej aniżeli uznaje to Trybunał. O ile ograniczenia są zrozumiałe w stosunku do wypowiedzi znieważających, o tyle na gruncie art. $49 \S 1$ k.w. mamy do czynienia - jak przyjmuje sam Trybunał - jedynie z uzewnętrznianiem negatywnych uczuć i emocji względem określonych podmiotów ${ }^{25}$. Te zaś nie podlegają kryterium prawdy i fałszu, z założenia nie zawierają jakichkolwiek argumentów odnoszących się do cech podmiotów czy ich działalności. Chodzi przecież o uzewnętrznienie ogólnego stosunku sprawcy do określonego podmiotu. Jednak zachodzący wówczas brak wkładu w debatę publiczna, przy jednoczesnym braku ujęcia wypowiedzi w formę znieważająca, nie oznacza automatycznie, że zachowanie takie musi podlegać odpowiedzialności wykroczeniowej. Nie wydaje się, jak widzi to Trybunał, by zachodził dychotomiczny podział na wypowiedzi, które stanowią udział w debacie publicznej, oraz te, które są karalne, wykraczając poza granice debaty. Należy przyjąć, że podmiot realizujący znamiona art. $49 \S 1$ k.w. świadomie korzysta ze sfery wolności wypowiedzi pozostającej poza polem debaty publicznej i krytyki organów państwa ${ }^{26}$ i jednocześnie brak jest podstaw do ingerencji w tę sferę poprzez reakcję penalną. Art. $49 \S 1$ k.w. jest zatem niekonstytucyjny.

W ten sposób dochodzimy do czwartego zarzutu względem wyroku Trybunału, a mianowicie - pozornie - przeprowadzonego przezeń testu klauzuli limitacyjnej art. 31 ust. 3 Konstytucji. Przede wszystkim należy zauważyć, iż wbrew optyce przyjętej przez Trybunał badany przepis należało poddać badaniu z punktu widzenia całej klauzuli limitacyjnej, a nie jedynie z punktu widzenia jej części w postaci testu proporcjonalności sensu largo. Zaniechanie Trybunału umożliwiło mu pominięcie choćby oceny, czy tak szeroki zakres karalności, jaki wynika $\mathrm{z}$ art. $49 \S 1$ k.w., nie narusza zasad demokratycznego państwa prawa, do czego upoważnia art. 31 ust. 3 Konstytucji. Należałoby wówczas wykazać, że zgodne z zasadami demokratycznego państwa prawa jest wprowadzenie odpowiedzialności wykroczeniowej za samo okazanie negatywnych uczuć, negatywnego (ujemnego) stosunku emocjonalnego do określonych podmiotów.

Także W. Jankowski, M. Bojarski oraz S. Hoc określają lekceważenie jako uzewnętrznianie negatywnych uczuć, negatywnego (ujemnego) stosunku emocjonalnego (W. Jankowski, w: T. Grzegorczyk (red.), op. cit., s. 213; M. Bojarski, op. cit., teza 2; S. Hoc, op. cit., s. 170-171).

26 Słusznie dostrzegają D. Egierska, W. Jankowski i S. Hoc, że w art. 49 § 1 k.w. właśnie nie chodzi wcale o krytykę (D. Egierska, w: J. Bafia, D. Egierska, I. Śmietanka, op. cit., s. 158; W. Jankowski, w: T. Grzegorczyk (red.), op. cit., s. 213; S. Hoc, op. cit., s. 170). 
Przechodząc do oceny przeprowadzenia przez Trybunał testu proporcjonalności sensu largo, należy zauważyć, że trudno jest podjąć polemikę z niepopartymi żadnymi argumentami deklaracjami zawartymi w uzasadnieniu wyroku. W stosunku do testu przydatności stwierdza bowiem Trybunał, że „ograniczenie wolności słowa, przez obłożenie sankcją wykroczeniową demonstracyjnego okazywania im w miejscach publicznych lekceważenia, musi być uznane za przydatne". Służy bowiem autorytetowi podmiotów wymienionych w art. 49 § 1 k.w., sprzyjając integracji społeczeństwa wobec najważniejszych dla niego wartości i zapobiegając erozji czynników konsolidujących wspólnotę polityczną. Zapomina jednak Trybunał o całym swoim dotychczasowym dorobku, w którym test przydatności pojmował jako odpowiedź na pytanie, czy według dostępnego stanu wiedzy, poprzez kryminalizację możliwe będzie osiagnięcie założonych celów społecznych ${ }^{27}$, czy środki prawnokarne nadają się obiektywnie do realizacji założonych celów. Jeśli celem jest budowanie i podtrzymywanie autorytetu podmiotów wymienionych $\mathrm{w}$ art. $49 \S 1 \mathrm{k}$.w. oraz konsolidacja społeczeństwa wobec najważniejszych dla niego wartości, to cele te osiagnąć można innymi drogami, ale nie poprzez zagrożenie sankcją wykroczeniową. Rzeczywistego autorytetu nie da się zbudować przymusem państwowym, tak samo, jak nie da się w ten sposób skonsolidować społeczeństwa.

Podobnie rozmija się Trybunał ze swoim dotychczasowym orzecznictwem oraz dorobkiem dogmatyki w zakresie testu konieczności ingerencji. Ogranicza się do deklaracji, zgodnie z którą ,kwestionowana regulacja jest konieczna dla realizacji założonego przez ustawodawcę celu, ponieważ brakuje innych, mniej dolegliwych instrumentów, mogących skutecznie zapobiegać mniej poważnym od znieważenia atakom na wymienione w przepisie podmioty". Nie wchodząc w głębszą analizę wymogu konieczności, należy zauważyć, że pomija Trybunał choćby konieczność wykazania, że w omawianym przypadku nie jest wystarczające pozostawienie reakcji na nieakceptowane zachowania oddziaływaniu społecznemu, w postaci chociażby wyrażonego oburzenia czy ostracyzmu. Jednym z elementów testu konieczności jest przecież wykazanie, że dla osiagnięcia założonego przez ustawodawcę celu ochrony określonej wartości konstytucyjnej nie jest wystarczające posłużenie się środkami pozaprawnymi, następnie prawnymi innymi niż karne, następnie istniejącymi rozwiązaniami prawnokarnymi,

27 Wyroki Trybunału Konstytucyjnego: z 16.7.2009 r., Kp 4/08, OTK-A 2009, nr 7, poz. 112; z 23.11.2009 r., P 61/08, OTK-A 2009, nr 10, poz. 150; z 9.10.2012 r., P 27/11, OTK-A 2012, nr 9, poz. 104; z 25.07.2013 r., P 56/11, OTK-A 2013, nr 6, poz. 85; z 10.12.2013 r., U 5/13, OTK-A 2013, nr 9, poz. 136. 
by na końcu wskazać, że niezbędna jest ingerencja ustawodawcza i poszerzenie zakresu karalności. Pierwszym etapem jest zawsze ocena środków pozaprawnych. Jak słusznie stwierdza H. Kołakowska-Przełomiec, „kryminalizacja nie powinna wkraczać w miejsce nie przestrzeganych norm społecznych, norm życia codziennego. Prawo karne nie powinno wkraczać tam, gdzie powinny funkcjonować inne formy kontroli społecznej"28. Również A. Gubiński wskazuje słusznie na środki całkowicie pozaprawne: kulturalne czy odwołujące się do oddziaływania moralnego ze strony zbiorowości ${ }^{29}$. Skuteczność prawa karnego powinna być rozpatrywana w kontekście środków polityki społecznej, edukacyjnej i kulturowej jako tych elementów, których współdziałanie z przepisami prawa karnego da lepsze rezultaty ${ }^{30}$. W przypadku celowości poprzestania wyłącznie na nich kryminalizacja nie spełnia wymogu konieczności. I. Andrejew, posługując się pojęciem posiłkowej roli prawa karnego, wskazuje, że nie jest ono jedynym ani głównym środkiem zwalczania przestępczości i spełnia rolę wtórną wobec przemian społecznych, kulturowych i ekonomicznych usuwających przyczyny przestępczości oraz w stosunku do działalności profilaktycznej i wychowawczej o charakterze niepenalnym ${ }^{31}$. Podobnie V. Krey i R. Esser ${ }^{32}$ wskazują na stopniowanie narzędzi kontroli społecznej jednostki, poczynając od tej sprawowanej przez rodzinę, szkołę, sąsiadów, społeczność, kościół, zakład pracy i stowarzyszenia, jako pozaprawnych narzędzi kontroli. Wszystkie one dysponują odpowiednim i specyficznym dla każdej z nich instrumentarium umożliwiającym nagradzanie zachowań pożądanych oraz piętnowanie zachowań naruszających przyjęte normy społeczne. Przeprowadzając test konieczności ingerencji, Trybunał powinien zatem rozpocząć od wykazania, że wobec demonstracyjnego okazywania lekceważenia podmiotom wymienionym w art. $49 \S 1$ k.w. nie jest wystarczające zdanie się na narzędzia reakcji pozaprawnej, zwłaszcza że biorąc pod uwagę charakter tych podmiotów, można się spodziewać żywej reakcji osób będących świadkami inkryminowanego zachowania.

Przeprowadzenie testu proporcjonalności sensu stricto wymaga wskazania wartości konstytucyjnej wymienionej w art. 31 ust. 3 Konstytucji, której ochrona uzasadnia ingerencję $\mathrm{w}$ sferę praw i wolności jednostki przez ustawodawce (materialna przesłanka ingerencji). W omawianym kontekście trafnie identyfikuje

28 H. Kołakowska-Przełomiec, Kryminalizacja-penalizacja i dekryminalizacja-depenalizacja, w: Jakość prawa, Warszawa 1996, s. 160.

29 A. Gubiński, Zasady prawa karnego, Warszawa 1996, s. 34.

30 T. Bojarski, Polskie prawo karne. Zarys części ogólnej, Warszawa 2006, s. 26.

31 I. Andrejew, Polskie prawo karne w zarysie, Warszawa 1989, s. 39.

32 V. Krey, R. Esser, Deutsches Strafrecht. Allgemeiner Teil, Stuttgart 2011, s. 1-2. 
Trybunał tę wartość jako porządek publiczny (pkt 1.2.3). Zastrzega jednocześnie, że wszystkie pozostałe przesłanki ,nie mają zastosowania w sprawie”. Oznacza to, że niezależnie od wcześniejszych rozważań w stosunku do przedmiotu ochrony art. $49 \S 1 \mathrm{k}$.w. do testu proporcjonalności sensu stricto zostaje powołany jedynie porządek publiczny, lecz nie prawa i wolności innych osób, czyli piastunów konstytucyjnych organów państwa ${ }^{33}$.

W doktrynie karnistycznej ,pod pojęciem porządku publicznego rozumie się uporządkowany odpowiednimi przepisami, wolny od zakłóceń bieg życia zbiorowego", a ,spokój publiczny [...] oznacza [...] niezakłócony stan równowagi psychicznej nieokreślonej liczby osób, przy czym wykroczenia przeciwko spokojowi publicznemu wywołują zakłócenia tego stanu (zaniepokojenie, oburzenie itp. reakcje ludzi)" ${ }^{34}$. Ochronę porządku publicznego przez art. $49 \S 1$ k.w. - zdaniem Trybunału - „należy - w kontekście niniejszej sprawy - rozumieć jako nakaz stworzenia w państwie ładu prawnego umożliwiającego względnie spokojną koegzystencję jednostek różniących się pomiędzy sobą poglądami. Jest oczywiste, że różnice światopoglądowe wpływają na wyrażane przez jednostki w debacie publicznej opinie, niekiedy emocjonalne, które mogą być czasem trudne do przyjęcia dla innych. To jednak musi pozostawać w sferze tolerancji (od łacińskiego tolero, -are, -avi, -atum - znosić), a więc umiejętności ścierpienia (cierpliwego znoszenia, wytrzymywania) cudzych opinii, których nie podzielamy" (pkt 3.4). Wolność wypowiedzi obejmuje bowiem również wypowiedzi szokujące, obraźliwe lub wprowadzające niepokój w państwie albo jakiejś części społeczeństwa (pkt 1.2.2). Zatem rozwiązanie kolizji między wolnością wypowiedzi a ochroną porządku publicznego powinno znaleźć rozstrzygnięcie w kierunku ochrony tej pierwszej wartości i stwierdzenia niekonstytucyjności art. $49 \S 1$ k.w. Rację ma Trybunał, gdy następnie stwierdza, że „w dobrze pojętym interesie państwa i społeczeństwa jest [...], by po pierwsze, różniące się między sobąjednostki nie okazywały sobie w przestrzeni publicznej jawnego lekceważenia i publicznie się nie znieważały, a po wtóre, by takie negatywne uczucia nie były w miejscach publicznych demonstracyjnie okazywane podmiotom o najwyższym $-\mathrm{z}$ woli ustrojodawcy - konstytucyjnym znaczeniu" (pkt 3.4). Nie daje to jednak podstaw do zwalczania takich niewątpliwie nagannych zachowań za pomocą kary aresztu albo grzywny. Czy jest bowiem w ogóle rolą prawa penalnego karanie za okazywanie uczuć?

33 Czy indywidualnych osób, które demonstracyjne lekceważenie ich odczytały jako odnoszące się do całego Narodu, którego są przedstawicielami, a nie ich indywidualnie i personalnie (por. S. Hoc, op. cit., s. 170).

34 A. Marek, op. cit., s. 117. 
Podsumowując tę część uwag, należy przyjąć, że skoro nie zakwestionował Trybunał trafności argumentacji przedstawionej przez RPO we wniosku, to nie przeprowadzając testu proporcjonalności sensu largo nie wykazał konstytucyjnej legalności utrzymywania art. $49 \S 1$ k.w. Wbrew zatem jego intencjom, uzasadnienie dowodzi naruszenia przez art. $49 \S 1$ k.w. art. 54 ust. $1 \mathrm{w}$ zw. $\mathrm{z}$ art. 31 ust. 3 Konstytucji.

Na zakończenie nie może karnista przemilczeć sformułowanego obok głównego nurtu rozważań poglądu Trybunału, zgodnie z którym Internet jest miejscem publicznym, o którym mowa w art. $49 \S 1$ k.w. (pkt 2.1.3). Już sama wykładnia językowa wskazuje, że miejscem publicznym jest teren lub pomieszczenie przeznaczone dla wszystkich ludzi. Samym miejscem zaś część jakiejś przestrzeni, na której ktoś przebywa, coś się znajduje lub odbywa ${ }^{35}$. Internet zaś („,między-sieć”, „sieć sieci”) to system połączeń między komputerami - sieć adresów IP przydzielonych hostom i serwerom połączonym za pomocą urządzeń sieciowych, komunikujących się za pomocą protokołu internetowego z wykorzystaniem infrastruktury telekomunikacyjnej ${ }^{36}$. Internet nie może być zatem uznany za miejsce ani tym bardziej za miejsce publiczne ${ }^{37}$. W żadnym aspekcie i w żadnej postaci również strona internetowa, forum, czat, blog, serwis internetowy itd. nie spełniają już samej językowej definicji miejsca ani tym bardziej miejsca publicznego, nie mogą one zatem również być uznane za miejsce publiczne na gruncie art. $49 \S 1$ k.w. Wszystkie treści dostępne w Internecie stanowią jedynie zapis danych na komputerach, trudno natomiast byłoby uznać twardy dysk takiego komputera, czyli nośnik magnetyczny, za miejsce i do tego miejsce publiczne. Wykładnia przyjęta przez Trybunał narusza zakaz wykładni rozszerzającej, a zatem zasadę nullumcrimen sine lege. Nie oznacza to jednocześnie, że zachowania podejmowane w Internecie nie mogą wypełniać znamion działania publicznego.

S. Dubisz (red.), Uniwersalny stownik języka polskiego, t. 2, Warszawa 2003, s. 839.

36 https://pl.wikipedia.org/wiki/Internet

37 Por. również analogicznie względem ,przestrzeni, w której rozchodzą się fale radiowe”: J. Kulesza, w: P. Daniluk (red.), op. cit., s. 926. 